\title{
MEKANISME KOPING PADA ODHA DENGAN PENDEKATAN TEORI ADAPTASI CALLISTA ROY
}

\author{
(Coping Mechanism on People Living with HIV Using Theory of Adaptation Callista Roy)
}

\author{
Sandu Siyoto*, Yuly Peristiowati*, Eva Agustina* \\ *STIKes Surya Mitra Husada Kediri \\ Email : siyotos@gmail.com
}

\begin{abstract}
ABSTRAK
Pendahuluan: Dampak negatif yang ditimbulkan oleh individu yang hidup dengan HIV/AIDS adalah masalah fisik, psikososial dan emosional, sehingga ODHA perlu untuk meningkatkan mekanisme koping kearah adaptif. Roy menjelaskan ada 3 stimulus yang dapat mempengaruhi mekanisme koping yaitu stimulus fokal, stimulus kontektual,stimulus residual. Tujuan penelitian ini adalah untuk mengetahui faktor yang berhubungan dengan mekanisme koping berdasarkan Teori Adaptasi Roy. Metode: Desain penelitian menggunakan analitik korelasional pendekatan cross sectional, 30 responden dipilih dengantehnik purposive sampling.Instrumen penelitian menggunakan kuesioner. Hasil: Hasil penelitian menunjukan stimulus fokal, stimulus kontektual, adan stimulus residual berhubungan dengan mekanisme koping pada ODHA, sebagian besar responden memiliki mekanisme koping negatif sebanyak 18 responden $(60.0 \%)$ dan mekanisme koping positif sebanyak 12 responden (40.0\%). Diskusi: Berdasarkan hasil analisa menunjukan ada hubungan stimulus fokal $p$-value $=$ 0.018 dan stimulus kontektual $p$-value $=0.004$, sedangkan stimulus residual tidak ada hubungannya dengan mekanisme koping pada ODHA di KDS friendship plus Kota Kediri.Selama bergabung dalam kelompok dukungan sebaya ODHA mempunyai wadah untuk mencurahkan perasaan dan emosi serta dapat berkomunikasi sosial dengan baik, sehingga adanya stimulus fokal dan kontektual dari KDS dapat menstimulasi respon kognator dan regulator yang dapat mempengaruhi fungsi fisiologis sehingga mampu beradaptasi secara adaptif.
\end{abstract}

Kata Kunci: Teori adaptasi Roy, Stimulus Fokal, Kontektual, Residual, Mekanisme Koping, ODHA.

\begin{abstract}
Introduction: The negative impact caused by people living with HIV/AIDS is a matter of physical, psychosocial and emotional, so that people living with HIV need to improve towards adaptive coping mechanisms. Roy explained that there are three stimulus that can influence the coping mechanisms, there are stimulus focal, contextual stimulus, stimulus residual. The purpose of this study was to determine the factors related with coping mechanisms based on the Roy Adaptation Theory. Methods: The study design using analytic correlational cross-sectional approach, 30 respondents were selected by purposive sampling technique. The research instrument used questionnaire. Results: The results showed focal stimulus, stimulus contextual, adan residual stimulus associated with coping mechanisms in people living with HIV, the majority of respondents have a negative coping mechanisms as many as 18 respondents $(60.0 \%)$ and positive coping mechanisms as much as 12 respondents $(40.0 \%)$. Discussion: Based on the analysis showed there is relationship stimulus focal $\mathrm{p}$-value $=0.018$ and contextual stimulus $\mathrm{p}$-value $=0.004$, while the residual stimulus doesn't have relation with the coping mechanisms of people living with HIV in KDS friendship plus Kediri. During join the peer support groups people with HIV has a place to share the feelings and emotions and be able to communicate social well, so that their focal and contextual stimuli can stimulate a response from KDS cognator and regulators that can affect physiological functions so they can adapt adaptively.
\end{abstract}

Keywords: Roy adaptation theory, Stimulus Focal, contextual, Residual, Coping Mechanisms, people living with HIV.

\section{PENDAHULUAN}

HIV/AIDS merupakan masalah kesehatan yang mengancam Indonesia dan banyak negara di seluruh dunia. Saat ini tidak ada negara yang terbebas dari masalah HIV/AIDS. HIV (Human Immunodeficiency Virus) adalah virus yang menyerang system kekebalan tubuh manusia lalu menimbulkan AIDS. AIDS (Acquired Immuno Deficiency Sindrom) merupakan kumpulan gejala penyakit yang disebabkan oleh virus HIV yang merusak sistem kekebalan tubuh manusia (Zein 2006)
Penderita HIV/AIDS mempunyai masalah terkait dengan mekanisme koping, karena masih banyaknya stigma negatif dari masyarakat tentang HIV/AIDS sehingga banyak penderita HIV/AIDS yang mengisolasi diri dari lingkungannya dan banyak penderita HIV/AIDS yang menganggap dirinya tidak berguna lagi. Dengan adanya gangguan psikis pada pasien HIV/AIDS sehingga berakibat juga pada penurunan sistem kekebalan tubuh dan sistem imun (Yayasan Spiritia 2006). 
Berdasarkan studi pendahuluan yang dilakukan peneliti di Kelompok Dukungan Sebaya Friendship Plus terdapat ODHA sebanyak 221 orang dan dari 10 penderita didapatkan 7 orang dengan mekanisme koping negatif seperti menutup diri, menganggap dirinya tidak berguna dan mengasingkan diri dari masyarakat, dan 3 orang dengan mekanisme koping positif terlihat dengan dirinya masih mempunyai rasa percaya diri yang tinggi,menggap dirinya patut menjadi tokoh dimasyarakat. Dinas kesehatan Kota Kediri, mulai tahun 2003 2015 dengan kumulatif ditemukan 644 orang terinfeksi HIV/AIDS, dari jumlah tersebut ditemukan 49 orang meninggal dan 595 orang masih hidup. Penderita HIV/AIDS sangat mudah merasa bersalah dan menerima penolakan dari sekitarnya, hal inidisebabkan karena anggapan bahwa tingkah laku mereka, terutama tingkah laku seksual, dapat membahayakan orang lain. Penderita HIV/AIDS akan mengalami berbagai stresor atau stimulus yang dapat mempengaruhi mekanisme koping, stimulus atau input yang masuk diantaranya adalah stimulus fokal, stimulus konstektual dan stimulus residual sehingga ODHA membutuhkan mekanisme koping yang tepat untuk upaya yang diarahkan pada pengelolaan stressor (Roy, Sr 2009). Individu yang utuh dan sehat, akan mampu berfungsi untuk memenuhi kebutuhan biopsikososial menggunakan koping yang positif maupun yang negatif. Untuk mampu beradaptasi tiap individu akan berespon terhadap kebutuhan fisiologis, konsep diri yang positif, mampu memelihara integritas diri, selalu berada pada rentang sehat sakit untuk memelihara proses adaptasi. Demikian besar dampak mekanisme koping adaptif untuk kualitas hidup pada pasien HIV reaktif maka diperlukan pertukaran informasi secara mendetail dan menyeluruh antar sesama pasien HIV. Model Adaptasi Roy menjelaskan adanya pertahanan dan peningkatan kemampuan proses adaptasi pasien terhadap stimulus kearah koping yang lebih adaptif.

Berdasarkan uraian diatas, maka penulis tertarik untuk melakukan penelitian dengan judul Analisis Faktor yang berhubungan dengan Mekanisme Koping pada ODHA (Orang Dengan HIV/AIDS) Berdasarkan pendekatan Teori Adaptasi Callista Roy di Kota Kediri.

\section{BAHAN DAN METODE}

Desain Penelitian ini menggunakan "Analitik Korelasional"dengan menggunakan model rancangan cross sectiona.lPopulasipenelitian ini semua ODHA yang ada di Kelompok Dukungan Sebaya Friendship Plus di Kota Kediri yang berjumlah 221 orang. Tehnik sampling Purposivedenganjumlah sampel 30 responden. Instrumen penelitian menggunakanKuesioner. analisis data menggunakan uji statistik Regresi Logistik $\alpha=0,05$.

\section{HASIL \\ Data Umum}

Data umum akan menyajikan karakteristik responden.Berdasarkan karakteristik responden menunjukkan sebagian besar usia resonden berumur 25-35 tahun sebanyak 20 (67\%), 18 responden $(60 \%)$ berjenis kelamin laki-laki. Sebagian besar sudah pernah mendapatkan informasi tentang HIV/AIDS sebanyak 22 responden $(73 \%)$ dan sebanyak 13 responden $(43 \%)$ telah terkena HIV/AIDS selama $\leq 1$ tahun.

\section{Data Khusus}

Tabel 1Mekanisme Koping pada ODHA di KDS Friendship Plus Kota Kediri

\begin{tabular}{llll}
\hline No. & Kategori & Frekuensi & $\begin{array}{l}\text { Presentas } \\
\text { e }\end{array}$ \\
\hline 1. & negatif & 18 & $60 \%$ \\
$2 . \quad$ positif & 12 & $40 \%$ \\
\hline Jumlah & 30 & 100 \\
\hline
\end{tabular}

Tabel 2.Stimulus fokal pada ODHA di KDS Friendship Plus Kota

\begin{tabular}{llll}
\hline No. & Kategori & Frekuensi & Prosentase \\
\hline 1. & Rendah & 10 & $33.3 \%$ \\
2. & Sedang & 8 & $26.7 \%$ \\
3. & Tinggi & 12 & $40.0 \%$ \\
\hline & & 30 & $100 \%$ \\
\hline
\end{tabular}


Mekanisme Koping ODHA Dengan Pendekatan Teori Adaptasi C. Roy (Sandu, dkk)

Tabel 3. Stimulus kontektual pada ODHA di KDS Friendship Plus Kota Kediri

\begin{tabular}{llll}
\hline No. & Kategori & Frekuensi & Presentasi \\
\hline 1. & Rendah & 12 & $40.0 \%$ \\
\hline 2. & Sedang & 10 & $33.3 \%$ \\
\hline 3. & Tinggi & 8 & $26.7 \%$ \\
\hline & & 30 & $100 \%$ \\
\hline
\end{tabular}

Tabel 4. Stimulus residual pada ODHA di KDS Friendship Plus Kota Kediri

\begin{tabular}{llll}
\hline No. & Kategori & Frekuensi & Presentasi \\
\hline 1. & Rendah & 17 & $56.7 \%$ \\
2. & Sedang & 7 & $23.3 \%$ \\
3. & Tinggi & 6 & $20.0 \%$ \\
\hline & & 30 & $100 \%$ \\
\hline
\end{tabular}

Tabel 5. Hasil Analisa Data : uji statistik regresi logistik faktor stimulus dengan mekanisme koping

\begin{tabular}{llc}
\hline No. & Kategori & Nilai Signifikan \\
\hline 1. & Stimulus Fokal & 0.018 \\
2. & Stimulus Kontektual & 0.004 \\
3. & Stimulus Residual & 0.111 \\
\hline
\end{tabular}

Berdasarkan uji statistik regresi logistik faktor yang paling dominan terhadap mekanisme koping adalah faktor stimulus kontektual

\section{PEMBAHASAN}

Hasil penelitian di KDS Kota Kediri di dapatkan bahwa sebagian besar ODHA memiliki mekanisme koping yang negatif yaitu sebanyak 18 responden dengan presentase $(60.0 \%)$. Stimulus fokal dengan kategori tinggi sebanyak 12 responden yaitu (40.0\%), stimulus fokal dengan kategori rendah sebanyak 10 responden yaitu sebesar (33.3\%) stimulus fokal dengan kategori sedang sebanyak 8 responden yaitu sebesar $(26.7 \%$,) dan stimulus fokal dengan kategori tinggi sebanyak 12 responden (40.0\%). Stimulus kontektual dengan kategori rendah adalah sebanyak 12 responden yaitu sebesar (40.0\%)responden dengan stimulus kontektual kategori sedang adalah sebanyak 10 responden (33.3\%) dan stimulus kontektual dengan kategori tinggi adalah sebanyak 8 respoden $(26.7 \%)$. stimulus residual dalam kategori rendah sebanyak 17 responden yaitu sebesar $(56.7 \%)$ dan yang memiliki stimulus residual dalam kategori tinggi yaitu sebesar 6 responden $(20.0 \%)$. Hasil analisis dari uji statistik regresi logistik menunjukan bahwa ada hubungan antara stimulus fokal dengan dengan nilai Uji Wald stimulus kontektual adalah 8.244 dan nilai signifikan $0.004<$ (0.05).

mekanisme koping pada ODHA dengan $p$ value $=0.018<(0.05)$. Stimulus kontektual dengan mekanisme koping menunjukan hasil $p$-value $=0.004<(0.05)$. stimulus residual dengan mekanisme koping menunjukan hasil $p$-value $=0.111>(0.05)$.

Mekanisme koping merupakan distorsi kognitif yang digunakan oleh seseorang untuk mempertahankan rasa kendali terhadap situasi,mengurangi rasa tidak aman, dan menghadapi situasi yang menimbulkan stress (Videbeck, 2011). Roy mengemukakan bahwa manusia sebagai sebuah sistim yang dapat menyesuaikan diri (adaptive system). Sebagai sistim yang dapat menyesuaikan diri manusia dapat digambarkan secara holistik (bio, psicho, Sosial) sebagai satu kesatuan yang mempunyai Input (masukan), Control dan Feedback Processes dan Output (keluaran/hasil). Proses kontrol adalah Mekanisme Koping yang dimanifestasikan dengan cara-cara penyesuaian diri. Lebih spesifik manusia didefinisikan sebagai sebuah sistem yang dapat menyesuaikan diri dengan proses mekanisme kognator dan regulator untuk mempertahankan adaptasi dalam empat 
cara-cara penyesuaian yaitu : Fungsi Fisiologis, Konsep diri, Fungsi peran, dan Interdependensi (Roy, Sr 2009).

Stimulus Fokalmerupakan stimulus yang secara langsung dapat mempengaruhi suatu individu untuk berperilaku menuju mekanisme koping yang adaptif. Dalam penelitian ini stimulus fokal adalah adanya stigma negatif dari masyarakat atau lingkungan sekitar dan penolakan keluarga terhadap ODHA yang dapat mempengaruhi seorang individu dalam menghadapi stimulus yang masuk untuk menuju respon mekanisme koping yang positif

Roy menjelaskan bahwa respon yang menyebabkan penurunan integritas tubuh akan menimbulkan suatu kebutuhan dan menyebabkan individu tersebut berespon melalui upaya atau perilaku tertentu. Setiap manusia selalu berusaha menanggulangi perubahan status kesehatan dan perawat harus merespon untuk membantu manusia beradaptasi terhadap perubahan ini. ${ }^{5}$

Stimulus kontektual merupakan stimulus yang dapat menunjang terjadinya sakit (faktor presipitasi) seperti keadaan tidak sehat. Keadaan ini tidak terlihat langsung pada saat ini, misalnya penurunan daya tahan tubuh,lingkungan yang tidak sehat dan isolasi sosial. Banyak ODHA yang ketika mereka mengalami gangguan psikis dari luar dan menyebabkan terganggunya psikis atau beban pikiran sehingga mengakibatkan sistem imun ODHA yang rentan akan terjadi penurunan sehingga akan mempengaruhi CD4 pada ODHA.

Stimulus residual adalah karakteristik atau riwayat seseorang dan timbul secara relevan sesuai dengan situasi yang dihadapi tetapi sulit diukur secara objektif. Stimulus residual merupakan sikap, keyakinan dan pemahaman individu yang dapat mempengaruhi terjadinya keadaan tidak sehat, atau disebut dengan Faktor Predisposisi, sehingga terjadi kondisi Fokal, misalnya : Persepsi pasien tentang penyakit, gaya hidup, dan fungsi peran.(Wilkins n.d., 2006)

Hal ini menunjukan bahwa ODHA yang mendapatkan stimulus fokal akan mempengaruhi mekanisme koping kearah yang negatif, karena masih banyak ODHA yang mendapatkan stigma dari masyarakat dan juga penolakan dari keluarga, sehingga ODHA sering merasa hidupnya tidak berguna lagi merasa gagal dalam hidup dan berakibat ke mekanisme koping yang negatif.

Koping yang efektif atau mekanisme koping yang positif menepati tempat yang sentral terhadap ketahanan tubuh dan daya penolakan tubuh terhadap gangguan maupun serangan suatu penyakit baik bersifat fisik maupun psikis dan social (Nursalam dan Ninuk 2013).

Dalam penelitian ini stimulus residual pada ODHA adalah sejauh mana presepsi ODHA serta keyakinan terhadap penyakit HIV/AIDS. Sebagian ODHA yang mempunyai persepsi bahwa HIV/AIDS adalah penyakit yang telah membuat hidup ODHA tidak ada gunanya lagi. Sehingga dengan adanya persepsi ODHA yang membut hidupnya tidak berguna lagi akan mempengaruhi dampak dari mekanisme koping, namun sebagian ODHA juga tidak mau memikirkan hal tersebut mereka sudah mengetahui cara pengobatan tentang HIV/AIDS dan akan tetap meneruskan hidupnya walaupun sebagai ODHA. Mereka percaya bahwa ARV adalah terapi yang dapat meningkatkan kualitas hidupnya.

Persepsi adalah pengamatan tentang objek , peristiwa atau hubungan-hubungan yang diperoleh dengan menyimpulkan informasi dan menafsirkan pesan proses menginterpretasikan rangsangan (input) dengan penerimaan informasi, dengan kata lain persepsi dapat juga didefenisikan sebagai segala sesuatu yang dialami manusia (Jalaludin Rakhmat 2007).

Faktor stimulus kontektual merupakan faktor yang paling dominan,dengan nilai $U j i$ Wald stimulus kontektual adalah 8.244 dan nilai signifikan $p$-value $0.004<0.05$. Stimulus kontektual dalam penelitian ini adalah adanya stimulus lain yang merangsang seseorang baik internal maupun eksternal serta mempengaruhi situasi dan dapat diobservasi, diukur, dan secara subjektif disampaikan oleh individu. Rangsangan ini muncul secara bersamaan dimana dapat menimbulkan respon mekanisme yang negatif (Roy, Sr 2009).

Roy mendefinisikan lingkungan sebagai semua kondisi yang berasal dari internal dan eksternal,yang mempengaruhi dan berakibat terhadap perkembangan dari perilaku seseorang dan kelompok untuk menuju ke mekanisme koping yang adaptif. Yang mempengaruhi suatu stimulus kontektual adalah adanya perubahan eksternal yaitu adanya gangguan fisik, kimiawi, psikologis. Sedangkan adanya perubahan internal yaitu 
adanya gangguan proses mental (pengalaman, emosional dan kepribadian) dan proses stressor biologis (sel maupun molekuler) (Nursalam, \& Kurniawati 2008).

\section{SIMPULAN DAN SARAN Simpulan}

Berdasarkan hasil uji statistik menggunakan Regresi Logistik kesalahan $\alpha<$ 0,05 didapatkan hasil signifikan nilai $\mathrm{P}=0.018$ $<0.05$ untuk stimulus fokal,stimulus kontektual $\mathrm{P}=0.004<0.05$ yang berarti ada hubungan dengan Mekanisme Koping pada ODHA dan stimulus residual $\mathrm{p}=0.111>$ $(0.05)$ yang berarti tidak ada hubungan dengan mekanisme koping pada ODHA, faktor yang paling dominan adalah faktor stimulus kontektual dengan nilai Uji Wald stimulus kontektual adalah 8.244 dengan nilai signifikan p-value $0.004<0.05$.

\section{Saran}

Bagi responden Diharapkan ODHA (Orang Dengan HIV/AIDS) lebih memiliki sikap percaya diri dalam melakukan aktifitas sehari-hari, dan juga ODHA bisa bertanya ketenaga kesehatan jika terjadi masalah fisik maupun psikis.

\section{DAFTAR PUSTAKA}

Jalaludin Rakhmat, 2007. Persepsi Dalam Proses Belajar Mengajar, Jakarta: rajawali pers.

Nursalam dan Ninuk, 2013. Asuhan Keperawatan pada Pasien Terinfeksi HIV/AIDS, Jakarta: Salemba Medika.

Nursalam, \& Kurniawati, N., 2008. Asuhan Keperawatan pada Pasien Terinfeksi HIV/AIDS., Jakarta: Salemba Medika.

Roy, Sr, C., 2009. The Roy adaptation model (3rd ed.). upper saddle River, $N J$ : Person. Tomey and Alligood M.R. 2006. Nursing theoriest, utilization and application, Mosby: Elsevier.

Wilkins, K.W.\&, Kluwer/Lippincott Williams $\&$ Wilkins.

Yayasan Spiritia, 2006. Lembaran Informasi tentang HIV dan AIDS untuk Orang Yang Hidup Dengan HIV dan AIDS (ODHA)., Jakarta: Yayasan spiritia.

Zein, U., 2006. seputar HIV/AIDS yang Perlu Anda Ketahui, medan: USU Press. 